\title{
UPAYA MENINGKATKAN HASIL BELAJAR PESERTA DIDIK MELALUI PENERAPAN MODEL KOOPERATIF TIPE THE POWER OF TWO BERBASIS ALAT PERAGA DI KELAS VII SMP YAPIS MANOKWARI
}

\author{
Irmansyah Karoror $^{1}$, Sri Wahyu Widyaningsih ${ }^{2}$, Sri Rosepda Br. Sebayang ${ }^{3}$, Irfan Yusuf ${ }^{4}$ \\ Irmansyahkaroror97@gmail.com \\ 1,2,3,4Program Studi Pendidikan Fisika Universitas Papua, Provinsi Papua Barat, Indonesia
}

Received: 2 Juni 2020

Revised: 3 Juni 2020

Accepted: 15 Juni 2020

\begin{abstract}
This study aims to determine how the application of the power of two type of cooperative learning model based on teaching aids to improve student learning outcomes in class VII A SMP YAPIS Manokwari. The instrument used was a learning achievement test to measure cognitive aspects and observation of students' activities in practicum to measure psychomotor aspects. This research is included in Classroom Action Research (CAR). Instrument analysis uses CVR and CVI to see the validity and reliability. Analysis of cognitive results using Microsoft Excel and psychomotor results using the Rasch Model. The results of this study indicate that, in the first cycle of classical completeness in the cognitive aspects by $65 \%$, and psychomotor aspects by $84 \%$. In second cycle of classical completeness in the cognitive aspects of $81 \%$, and psychomotor aspects by $90 \%$. This shows that learning using the power of two cooperative model based on teaching aids can improve student learning outcomes.
\end{abstract}

\begin{abstract}
Abstrak: Penelitian ini bertujuan untuk mengetahui bagaimana penerapan model pembelajaran kooperatif tipe the power of two berbasis alat peraga untuk meningkatkan hasil belajar peserta didik di kelas VII A SMP YAPIS Manokwari. Instrumen yang digunakan adalah tes hasil belajar untuk mengukur aspek kognitif dan observasi aktivitas peserta didik dalam praktikum untuk mengukur aspek psikomotorik. Penelitian ini termasuk dalam Penelitian Tindakan Kelas (PTK). Analisis intrumen menggunakan CVR dan CVI untuk melihat validitas dan reliabilitas. Analisis hasil kognitif menggunakan Microsoft Excel dan hasil psikomotorik menggunakan Rasch Model. Hasil dari penelitian ini menunjukkan bahwa, pada siklus I ketuntasan klasikal pada aspek kognitif sebesar 65\%, dan aspek psikomotorik sebesar 84\%. Siklus II ketuntasan klasikal pada aspek kognitif sebesar $81 \%$, dan aspke psikomotorik sebesar 90\%. Hal ini menunjukkan bahwa pembelajaran dengan menggunakan model kooperatif tipe the power of two berbasis alat peraga dapat meningkatkan hasil belajar peserta didik.
\end{abstract}

Kata kunci:Hasil belajar, kooperatif tipe the power of two, dan metode PTK.

\section{PENDAHULUAN}

Pendidikan merupakan suatu kebutuhan mutlak yang harus dipenuhi umat manusia sepanjang hayat. Tanpa adanya suatu proses pendidikan mustahil suatu kelompok manusia dapat hidup berkembang sejalan dengan aspirasi untuk maju, sejahtera dan bahagia. Proses pendidikan yang dilaksanakan dengan tertib, teratur, efektif dan efisien akan mempercepat proses pembudayaan bangsa berdasarkan tujuan nasional sebagaimana tercantum dalam 
alinea IV Pembukaan UUD 1945 yang di dukung oleh adanya kurikulum. Guru memegang peran penting dalam pelaksanaan kurikulum maka guru pulalah yang menciptakan kegiatan belajar mengajar bagi murid-muridnya. Guru dituntut harus mampu menciptakan situasi belajar yang aktif, menggairahkan, penuh kesungguhan, mampu mendorong kreativitas anak dan dapat membentuk kepribadian atau akhlak anak untuk memiliki rasa peduli terhadap orang lain dan juga rasa tanggung jawab (Lovisia, E, 2019).

Seiring berkembangnya Ilmu Pengetahuan dan Teknologi (IPTEK) serta terjadinya perubahan dalam tatanan kehidupan bermasyarakat dan bernegara merupakan poin penting yang harus ditanggapi dan dipertimbangkan dalam pengembangan kurikulum pada setiap jenjang pendidikan. Pengembangan kurikulum merupakan sesuatu hal yang dapat terjadi kapan saja sesuai dengan kebutuhan. Perubahan kurikulum yang terakhir adalah Kurikulum 2013 (K13) yang diterapkan tepatnya pada bulan Juli 2013.

(Permendikbud No. 70 tahun 2014) menyatakan bahwa "kurikulum 2013 bertujuan untuk mempersiapkan manusia Indonesia agar memiliki kemampuan hidup sebagai pribadi dan warga negara yang beriman, produktif, kreatif, inovatif, dan afektif serta mampu berkontribusi pada kehidupan bermasyarakat, berbangsa, bernegara, dan peradaban dunia". Kurikulum 2013 lebih mengedepankan aspek afektif, kognitif, dan psikomotorik serta memberikan keleluasaan pada setiap sekolah untuk mengembangkannya sesuai kondisi satuan pendidikan, kebutuhan peserta didik dan potensi daerah.

Pendidikan merupakan salah satu aspek yang penting dalam meningkatkan kualitas sumber daya manusia dalam menghadapi perkembangan teknologi yang disertai dengan perkembangan Ilmu Pengetahuan Alam (IPA). Perkembangan yang begitu pesat, menggugah para pendidik untuk merancang dan melaksanakan pendidikan yang lebih terarah penguasaan konsep IPA yang dapat menunjang dalam kehidupan bermasyarakat (Ariani, T, 2019). SMP YAPIS Manokwari merupakan salah satu sekolah yayasan Islam yang dalam pelaksanaan proses pembelajarannya telah menerapkan Kurikulum 2013. Salah satu masalah pokok dalam pembelajaran pada pendidikan formal (sekolah) ini adalah masih rendahnya daya serap siswa. Hal ini nampak dari prestasi hasil belajar siswa yang kurang memuaskan. Berdasarkan hasil wawancara peneliti dengan guru pengampu mata pelajaran Ilmu Pengetahuan Alam (IPA) pada kelas VII semester Gasal 2019-2020, diperoleh data nilai peserta didik saat menjawab soal fisika ranah C1-C3 yang biasa digunakan oleh guru, dan terlihat ketuntasan nilai peserta didik tergolong masih rendah, yaitu rata-rata $48 \%$ dengan Kriteria Ketuntasan Minimal (KKM) 65. 
Hal tersebut menjadi alasan mengapa pada mata pelajaran IPA khususnya bidang fisika belum menerapkan soal-soal berpikir tingkat tinggi yang identik berada pada ranah kognitif $\mathrm{C}_{4}-\mathrm{C}_{6}$ seperti yang diharapkan pada kurikulum 2013. Hal tersebut dikarenakan sumber belajar seperti alat peraga yang digunakan masih kurang lengkap, pendidik masih menggunakan model pembelajaran yang tidak bervariasi dan monoton, sehingga membuat peserta didik terlihat kurang bersemangat dan hanya cenderung mendengarkan penyampaian materi dari guru tanpa memberikan respon balik, karena kepasifan dari peserta didik ini sehingga membuat guru hanya bisa melihat aspek kognitif setiap peserta didik setelah 3 bulan berjalan. Faktor lain di karenakan mereka berada pada posisi masa transisi Sekolah Dasar (SD) ke Sekolah Menengah Pertama (SMP).

(Witarsa et al, 2017) dengan tegas menyatakan bahwa SD saat ini lebih berorientasi terhadap pembelajaran yang mengutamakan aspek kognitif peserta didik. Seringkali guru asik memberikan ceramah yang bersifat hafalan, dan peserta didik duduk manis mendengarkan penjelasan guru, alhasil peserta didik tersebut mengalami kesulitan dalam hal kemampuan psikomotorik, sehingga hal tersebut terbawa sampai mereka berada dijenjang SMP. Terdapat pula sikap bawaan dari SD, seperti; saling melapor siswa satu dengan yang lain kepada guru, sering terlambat mengumpulkan tugas, terlalu banyak main, masih malu-malu dengan teman sekelasnya, buku catatan beberapa mata pelajaran masih digabungkan menjadi satu.

Salah satu alternatif untuk mengatasi problematika tersebut dengan menerapkan suatu model pembelajaran yang melibatkan keaktifan peserta didik dalam proses pembelajaran, tentunya akan meningkatkan hasil belajar dari peserta didik itu sendiri, yaitu pembelajaran kooperatif tipe the power of two. Menurut (Naida, 2018) tipe the power of two mempermudah peserta didik dalam memahami materi pelajaran sehingga akan berdampak terhadap peningkatan hasil belajar. Model pembelajaran kooperatif tipe The Power of Two berarti menggabungkan dua kepala dalam hal ini adalah membentuk kelompok kecil, yaitu masing-masing siswa berpasangan. Kegiatan ini dilakukan agar munculnya suatu sinergi yakni dua kepala lebih baik dari satu (Pratomo, R. H. S, 2017). Salah satu faktor yang berpengaruh terhadap peningkatan hasil belajar yaitu dengan menggunakan media atau alat bantu mengajar. Berdasarkan hasil wawancara, peserta didik lebih memahami konsep akan suatu materi bila disertai dengan media atau alat bantu. Terdapat kelebihan dari suatu pembelajaran bila menggunakan peragaan-peragaan yang konkret yaitu, agar peserta didik lebih mudah mengingat, menceritakan dan menerima pelajaran dengan antusias. Proses kegiatan dalam pembelajaran ini diharapkan dapat mencapai keberhasilan kegiatan belajar 
mengajar ditandai dengan adanya peningkatan kualitas pendidik dan juga meningkatnya hasil belajar peserta didik.

\section{LANDASAN TEORI}

Hasil belajar adalah bila seseorang telah belajar akan terjadi tingkah laku pada orang tersebut, misalnya dari tidak tahu menjadi tahu, dan dari tidak mengerti menjadi mengerti. Tingkah laku disini memiliki dua unsur subjektif dan unsur motoris. Unsur subjektif adalah unsur rohaniah sedangkan unsur motoris adalah unsur jasmaniah (Naida, 2018). Hasil belajar dapat dilihat melalui tes yang digunakan sebagai evaluasi untuk mengukur kemampuan peserta didik sesuai dengan indikator keberhasilan pembelajaran. Tes evaluasi pembelajaran yang sering digunakan adalah taksonomi Bloom. Ranah belajar menurut taksonomi Bloom revisi yang dikutip oleh (Effendi, 2016) tujuan pendidikan dibagi menjadi tiga ranah (kognitif, afektif, dan psikomotorik), namun peneliti hanya menggunakan dua ranah dalam penelitian ini yaitu ranah kognitif dan psikomotorik.

1. Ranah kognitif (cognitive domain) yang berisi perilaku-perilaku yang menekankan aspek intelektual, seperti pengetahuan, pengertian, dan keterampilan berpikir. Ranah kognitif yang difokuskan pada penelitian ini meliputi; $\mathrm{C}_{1}$ (mengingat), $\mathrm{C}_{2}$ (memahami), dan $\mathrm{C}_{3}$ (menerapkan).

2. Ranah Psikomotor (psychomotor domain) yang berisi perilaku-perilaku yang menekankan aspek keterampilan motorik seperti tulisan tangan, mengetik, berenang, dan mengoperasikan mesin. Ranah psikomotor yang difokuskan pada penelitian ini meliputi; $\mathrm{P}_{1}$ (meniru), $\mathrm{P}_{2}$ (manipulasi), dan $\mathrm{P}_{3}$ (presisi).

Model yang digunakan dalam penelitian ini, yaitu model kooperatif. Model kooperatif didalamnya terdiri atas beberapa tipe, namun yang digunakan oleh peneliti yaitu tipe the power of two. Menurut (Bintaro, 2018) model pembelajaran the power of two merupakan aktivitas yang digunakan untuk meningkatkan pembelajaran dan menegaskan manfaat dari sinergi, bahwa dua kepala adalah lebih baik dari pada satu. Penerapan model ini lebih menekankan pada aktivitas peserta didik yang dilakukan secara berpasangan dan mengutamakan kerjasama. Setiap model pembelajaran dikenal adanya sintaks (pola) urutan yang menggambarkan keseluruhan alur serangkaian kegiatan pembelajaran. Budiharti dan Devi (2016: 12) menjelaskan bahwa sintaks dalam penerapan model pembelajaran kooperatif tipe the power of two terdapat 5 langkah: 1) tahapan memberikan pertanyaan, 2) tahapan meminta peserta didik menjawab pertanyaan secara individual, 3) tahapan meminta 
berpasangan, 4) tahapan meminta peserta didik membuat jawaban baru, dan 5) tahapan meminta peserta didik membandingkan jawaban setiap pasangan dalam kelas.

Penerapan model pembelajaran ini dengan menggunakan alat peraga pada mata pelajaran IPA khususnya bidang fisika didasari kenyataan bahwa pada bidang fisika terdapat banyak pokok bahasan yang memerlukan alat bantu untuk menjelaskannya, salah satunya pada materi objek IPA dan pengamatannya yang diajarkan pada peserta didik SMP kelas VII semester satu.

Alat peraga merupakan media pengajaran yang membawakan konsep-konsep yang dipelajari. Alat peraga dapat menyajikan hal-hal yang abstrak dalam bentuk benda-benda atau fenomena-fenomena kongkrit yang dapat dilihat, dipegang, diubah-ubah sehingga hal-hal yang bersifat abstrak lebih mudah dipahami. Tujuan penggunaan alat peraga dalam pembelajaran ini untuk mencapai pembelajaran yang lebih optimal.

\section{METODE PENELITIAN}

Metode penelitian yang dilakukan adalah Penelitian Tindakan Kelas (PTK). Tujuan penelitian ini yaitu untuk meningkatkan hasil belajar peserta didik melalui penerapan model pembelajaran kooperatif tipe the power of two berbasis alat peraga di kelas VII SMP YAPIS Manokwari pada bidang fisika pokok bahasan objek IPA dan pengamatannya. Penelitian berlangsung selama dua siklus, masing-masing siklus terdiri dari dua kali pertemuan. Serangkaian penelitian dilaksanakan pada bulan Oktober 2019 sampai Februari 2020, semester Gasal tahun ajaran 2019/2020. Subjek penelitian yaitu 31 peserta didik di kelas VII A SMP YAPIS Manokwari. Teknik pengumpulan data meliputi observasi aktivitas peserta didik, observasi keterlaksanaan pembelajaran guru, dan tes. İnstrumen yang digunakan berupa lembar observasi aktivitas peserta didik, lembar observasi keterlaksanaan pembelajaran guru, tes siklus berupa soal pilihan ganda, dan Rencana Pelaksanaan Pembelajaran (RPP). İnstrumen tersebut akan divalidasi oleh validator ahli, kemudian hasil penilaian validasi tersebut dianalisis menggunakan pendekatan Content Validity Ratio (CVR) danContent Validity Index (CVI). Instrumen dikatakan valid jika CVR dan CVI berada pada kisaran nilai 0 s.d 1. Menurut (Arikunto, 2013) jika pernyataan setiap aspek dinyatakan valid, selanjutnya akan dianalisis reliabilitas menggunakan rumus alpha. Kriteria reliabilitas tes dikatakan reliabel jika harga $r_{11}$ dari perhitungan lebih besar dari harga $\mathrm{r}$ pada tabel product moment. Hasil analisis validasi instrumen sebagaimana ditunjukkan pada Tabel 1.

Tabel 1. Analisis validasi instrumen penelitian 


\begin{tabular}{lllllll}
\hline \multirow{2}{*}{ No. Jenis Instrumen } & & \multicolumn{2}{c}{ CVI } & \multirow{2}{*}{ Kriteria Reliabilitas } & Kriteria \\
\cline { 3 - 4 } & & A1 A2 & A3 & & & \\
\hline $\mathbf{1}$ & RPP & $1,01,0$ & 1,0 & Valid & 0,9989 & Reliabel \\
$\mathbf{2}$ & LKPD & $0,60,6$ & 1,0 & Valid & 0,9947 & Reliabel \\
$\mathbf{3}$ & Soal siklus I & $1,01,01,0$ & Valid & 0,9999 & Reliabel \\
$\mathbf{4}$ & Soal siklus II & $1,01,01,0$ & Valid & 0,9999 & Reliabel \\
$\mathbf{5}$ & Lembar observasi & $1,01,0$ & 0,6 & Valid & 0,9978 & Reliabel \\
& keterlaksanaan pembelajaran & & & & \\
\hline
\end{tabular}

Instrumen peneletian setelah divalidkan maka sudah siap untuk digunakan, kecuali instrumen tes. Peneliti tentunya akan melakukan uji coba instrumen tes terlebih dahulu di kelas VIII B dengan tujuan melihat instrument tes tersebut memenuhi kriteria validitas item, reliabilitas, taraf kesukaran butir soal, dan juga daya pembeda. Berdasarkan kelayakan instrumen tes soal pada setiap kriteria diperoleh valid, reliabel, memenuhi indeks kesukaran dan indeks diskriminasi, sehingga instrumen tes dapat digunakan di kelas penelitian.

\section{HASIL DAN PEMBAHASAN}

\section{Hasil Belajar Psikomotorik}

Menurut (Nurbudiyani, 2013) ranah psikomotor merupakan kemampuan bertindak seseorang setelah menerima suatu pengalaman belajar. Ranah psikomotorik merupakan ranah yang berkaitan dengan keterampilan (skill) atau kemampuan bertindak setelah seseorang menerima pengalaman belajar tertentu. Ranah ini diukur dengan mengamati dan menilai keterampilan siswa saat melakukan praktikum. Penilaian hasil belajar psikomotor mencakup: kemampuan menggunakan alat dan sikap kerja, kemampuan menganalisis suatu pekerjaan dan menyusun urut-urutan pengerjaan, kecepatan mengerjakan tugas, kemampuan membaca gambar dan atau simbol, keserasian bentuk dengan yang diharapkan dan atau ukuran yang telah ditentukan (Rosa, F. O, 2015).Penilaian hasil belajar psikomotorik dapat dilakukan menggunakan pengamatan langsung berupa observasi. Observasi merupakan salah satu teknik pengumpulan data yang berkaitan dengan proses kerja. Penilaian psikomotorik peserta didik menggunakan 3 ranah, yaitu: P1, P2, dan P3. Sebaran kemampuan hasil belajar psikomotorik untuk setiap siklusnyadianalisis menggunakan item variable maps dengan melihat kemampuan kriteria tinggi ditandai dengan logit yang lebih dari 0 . 


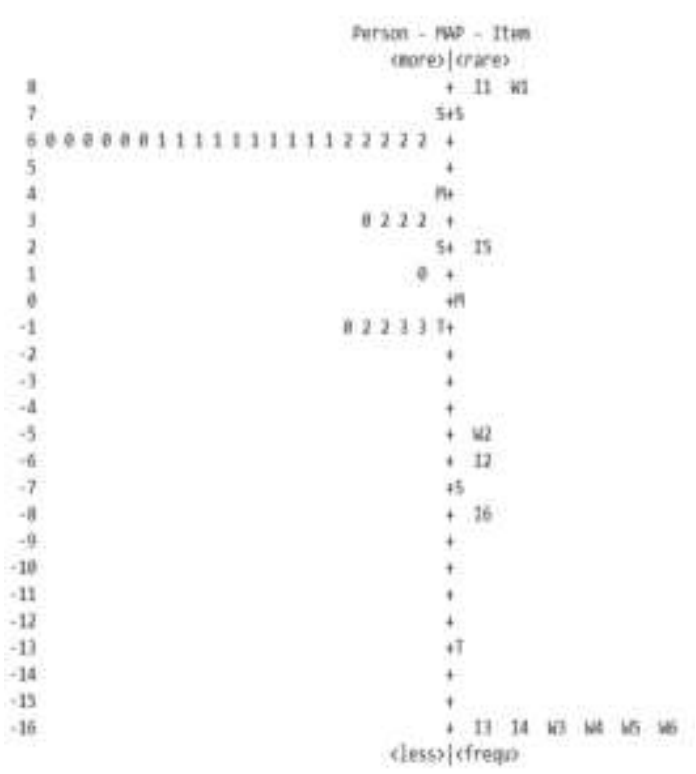

Gambar 1. Peningkatan aktivitas peserta didik siklus 1

Gambar 1. menjelaskan tentang sebaran kemampuan dari 31 peserta didik dan sebaran tingkat kesukaran setiap item. Pelabelan $(01,02,03,06,07,08,10,11,12,13,14,15,16,17,18$, 19, 20, 21, 23, 24, dan 25)adalah peserta didik yang memiliki nilai logit +6 . Selanjutnya pada label $(09,22,27$, dan 28) adalah peserta didik dengan logit +3 . Kemudian pada peserta didik (04) memiliki logit +1 . Sedangkan nomor $(05,26,29,30$, dan 31) memiliki nilai logit - 1 . Kemampuan dalam kriteria tinggi ditandai dengan logit yang lebih dari 0. Indikator ini menunjukkan bahwa terdapat 26 peserta didik yang memiliki nilai yang sangat baik.Sedangkan 5 peserta didik mendapatkan nilai yang kurang maksimal.

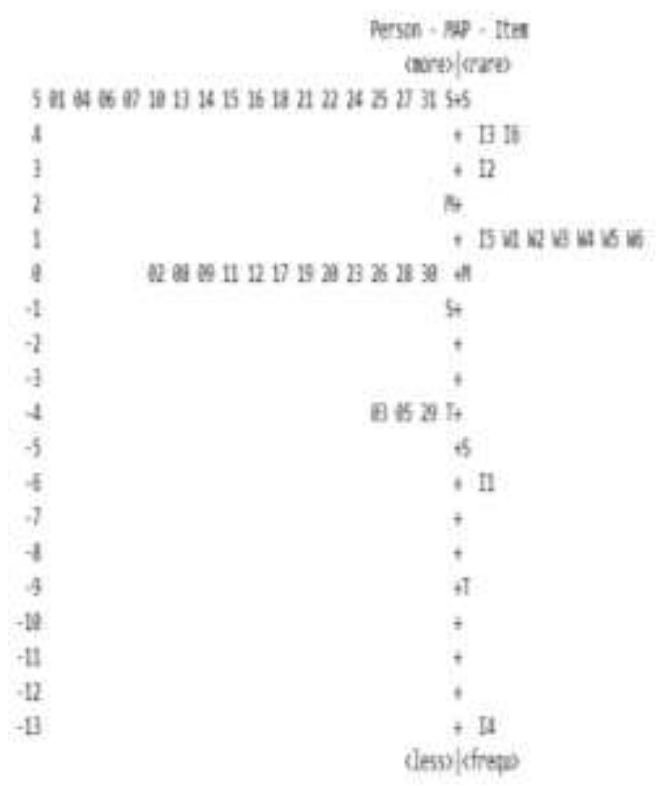

Gambar 2. Peningkatan aktivitas peserta didik siklus 2 
Gambar 2. menjelaskan tentang sebaran kemampuan dari 31 peserta didik dan sebaran tingkat kesukaran setiap item. Pelabelan $(01,04,06,07,10,13,14,15,16,18,21,22,24,25$, 27 dan 31) adalah peserta didik yang memiliki nilai logit +5 . Selanjutnya pada label $(02,08$, $09,11,12,19,20,23,26,28$, dan 30) adalah peserta didik dengan logit 0. Kemudian pada peserta didik $(03,05$, dan 29) memiliki logit - 4. Kemampuan dalam kriteria tinggi ditandai dengan logit yang lebih dari 0. Indikator ini menunjukkan bahwa terdapat 28 peserta didik yang memiliki nilai yang sangat baik. Sedangkan 3 peserta didik mendapatkan nilai yang kurang maksimal.

Selama proses penyampaian materi oleh guru, terdapat beberapa peserta didik yang masih sibuk sendiri, dan sesekali ada yang melamun. Sehingga proses pembelajaran kurang optimal. Namun, ketika memasuki tahap pembagian kelompok dan melakukan aktivitas psikomotorik, peserta didik menjadi antusias dalam pembelajaran. Hal ini sejalan dengan (Umar, 2011) bahwa peserta didik lebih senang bekerja secara kolaboratif. Sistem pembagian kelompok secara berpasangan dengan menyatukan peserta didik yang pandai dan kurang pandai, dengan harapan dapat membantu kesulitan belajar anggota kelompok yang kurang aktif. Tahap pengamatan pelaksanaan pembelajaran pada siklus II terhadap keterampilan peserta didik sedikit mengalami hambatan. Sebab alat praktikum yang tersedia kurang banyak. Sehingga setiap kelompok secara bergantian menggunakannya. Peserta didik begitu antusias dalam pembelajaran karena didukung dengan rasa semangat belajar mereka dalam mencoba alat peraga. Konsep ini sejalan dengan (Febriyono dan Widjanarko, 2014) bahwa alat peraga mempunyai peranan penting dalam menciptakan pembelajaran lebih efektif dengan jalan meningkatkan semangat belajar peserta didik. Sehingga hasil penilaian terkait keterampilan aktivitas peserta didik terbilang baik. Penjelasan terkait perbandingan jumlah peningkatan keterampilan peserta didik dari siklus I sampai siklus II dapat dilihat dalam Gambar 3.

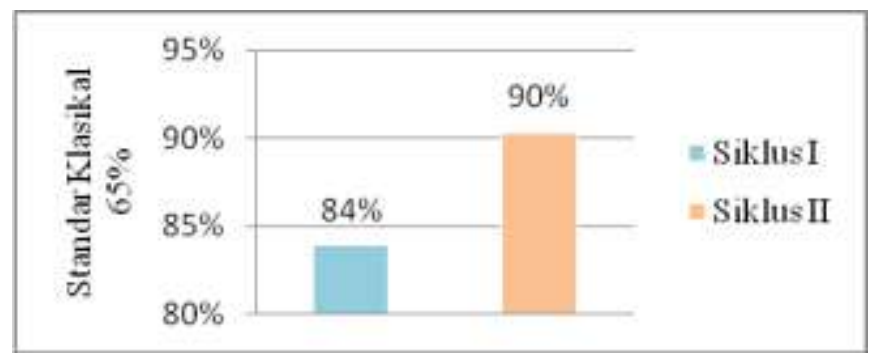

Gambar 3.Perbandingan hasil peningkatan psikomotorik

Terlihat pada Gambar3. bahwa secara klasikal ketuntasan psikomotorik peserta didik pada siklus I dan II terbilang baik. Hasil tersebut menunjukkan bahwa telah terjadi peningkatan Puplished at https://ojs.stkippgri-lubuklinggau.ac.id/index.php/SJPIF 
hasil belajar psikomotorik peserta didik. Hal ini sejalan dengan penelitian (Nurbaini, 2020)yang menyatakan bahwa terdapat peningkatan psikomotorik peserta didik pada setiap pertemuan dengan menerapkan model pembelajaran kooperatif tipe the power of two.

\section{Hasil Belajar Kognitif}

Hasil belajar kognitif merupakan kemampuan kognisi yang menimbulkan perubahan perilaku meliputi beberapa jenjang atau tingkat (Purwanto, 2010). Ranah kognitif adalah ranah yang mencakup kegiatan mental (otak) yaitu kemampuan yang dimiliki oleh seorang siswa yang mencakup menghafal/remember (C1), memahami/understand (C2), menerapkan/apply (C3), menganalisis/analyse (C4), mengevaluasi/evaluate (C5), dan membuat/create (C6). Ranah kognitif dapat diukur menggunakan tes yang dikembangkan dari materi optik yang telah didapatkan di sekolah (Rosa, F. O, 2015). Tujuan pengukuran ranah kognitif untuk melihat tingkat pemahaman peserta didik dalam mencapai tujuan instruksional. Berdasarkan penelitian yang dilakukan, bahwasannya hasil belajar peserta didik telah meningkat setelah diterapkannya model pembelajaran kooperatif tipe the power of two di kelas VII A SMP YAPIS Manokwari. Peningkatan hasil belajar kognitif dapat dilihat pada Gambar 4.

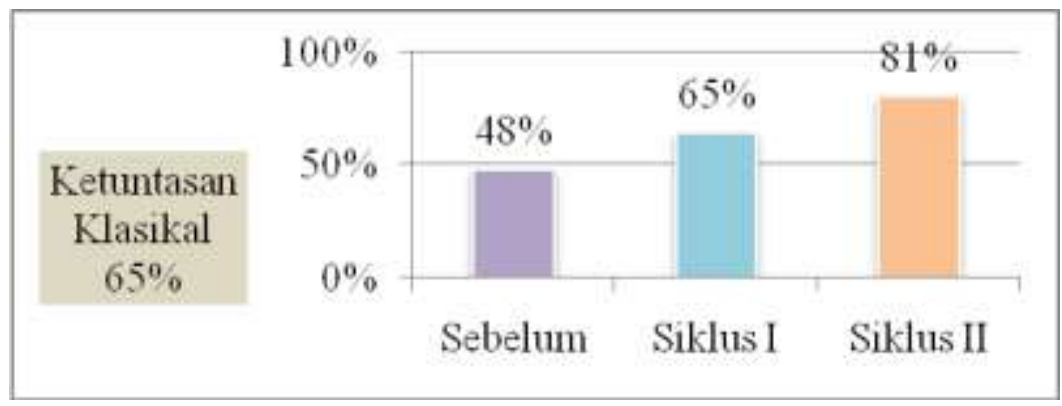

Gambar 4. Ketuntasan belajar klasikal

Data hasil penelitian menunjukkan bahwa, siklus I mengalami ketuntasan belajar sebesar 65\%. Meskipun hasil belajar peserta didik telah mencapai standar klasikal, peneliti tetap melanjutkan ke tindakan siklus II dengan tujuan untuk melakukan perbandingan serta memperbaiki kekurangan pada siklus I. Konsep ini sejalan dengan (Valia, 2015)yang menyatakan bahwa hasil belajar peserta didik mengalami peningkatan apabila adanya perbaikan pada model dan strategi pembelajaran. Guru berupaya semaksimal mungkin melakukan perbaikan terhadap kekurangan yang dialami. Perbaikan ini mengakibatkan terjadinya peningkatan hasil belajar pada siklus II sebesar $81 \%$. 
Indikator keberhasilan ketuntasan belajar peserta didik pada siklus I dan siklus II telah mencapai standar klasikal yaitu 65\%. Hal ini menunjukkan bahwa model pembelajaran kooperatif tipe the power of two dapat meningkatkan hasil belajar kognitif peserta didik kelas VII A SMP YAPIS Manokwari. Hasil penelitian ini sejalan dengan penelitian yang dilakukan oleh (Dewi dan Qubaniah, 2018)yang menyatakan bahwa penerapan model pembelajaran kooperatif tipe the power of two dapat memberikan pengaruh yang tinggi terhadap hasil belajar peserta didik pada materi Sistem Pencernaan Manusia di kelas VIII MTs Raudlatul Firdaus Kubu Raya.

\section{SIMPULAN DAN SARAN}

Berdasarkan penelitian disimpulkan bahwa terjadi peningkatan hasil belajar peserta didik melalui penerapan model pembelajaran kooperatif tipe the power of two berbasis alat peraga di kelas VII A SMP YAPIS Manokwari. Hal ini didukung dengan temuan bahwa:

1. Peningkatan hasil belajar kognitif peserta didik secara klasikal pada siklus I sebesar $65 \%$ yaitu 20 peserta didik yang memiliki nilai diatas KKM. Pada siklus II secara klasikal sebesar $81 \%$ yaitu 25 peserta didik memiliki nilai diatas KKM.

2. Peningkatan hasil belajar psiokomotorik peserta didik secara klasikal pada siklus I sebesar $84 \%$ dan siklus II sebesar $90 \%$.

Berdasarkan hasil penelitian, maka peneliti memberikan beberapa saran kepada beberapa pihak sebagai berikut:

1. Guru mata pelajaran IPA diharapkan dapat menerapkan model kooperatif tipe the power of two dalam proses pembelajaran.

2. Kepala sekolah hendaknya menyediakan fasilitas laboratorium IPA, sehingga dapat menunjang keberhasilan model pembelajaran yang akan digunakan.

3. Bagi peneliti lainnya yang ingin menggunakan model ini, diharapkan untuk melakukan penelitian terhadap ranah kognitif $\mathrm{C}_{4}-\mathrm{C}_{6}$.

\section{DAFTAR PUSTAKA}

Ariani, T. (2019). Perbedaan Hasil Belajar Fisika Menggunakan Model Pembelajaran Student Team Achievement Division (STAD) dan Model Pembelajaran Teams Games Tournament (TGT) Di SMP Negeri Air Lesing. Jurnal Sains dan Pendidikan Fisika, $14(2)$.

Arikunto, S. (2013). Dasar-dasar Evaluasi Pendidikan. Jakarta: Bumi Aksara. 
Dewi, Kartika, dan Mahwar Qubaniah. (2018). Metode Pembelajaran The Power of Twoterhadap Hasil Belajar Siswa pada Materi Sistem Pencernaan Manusia di MTS Raudlatul Firdaus Kubu Raya. Bioeducation, 5 (2),39.

Effendi, Ilham. (2016). Pengaruh Pemberian Pre-Test dan Post-Test Terhadap Hasil Belajar Mata Diklat Hdw.Dev.100.2.A pada Siswa SMK Negeri 2 Lubuk Basung. Volt, 1 (2), 83.

Febriyono, Oddie, dan Dwi Widjanarko. (2014). Penerapan Alat Peraga Berbasis LED untuk Meningkatkan Hasil Belajar Siswa pada Kompetensi Pengetahuan Pemeriksaan dan Troubleshooting Motor Starter Tipe Planetari. Automotive Science and Education Journal, 3 (2), 48.

Lovisia, E. (2019). Penerapan Model Pembelajaran Kooperatif Tipe Studentteams achievement division (STAD) pada pembelajaran fisika siswa kelas X SMA Negeri 7 Lubuklinggau. Silampari Jurnal Pendidikan Ilmu Fisika, 1(1), 1-12.

Mendikbud. 2013. Permendikbud Nomor 70 Tahun 2013 tentang Kerangkas Dasar dan Struktur Kurikulum Sekolah Menengah Kejuruan/Madrasah Aliyah Kejuruan. Jakarta: Menteri Pendidikan dan Kebudayaan.

Naida, Fadhli. (2018). Penerapan Strategi Pembelajaran The Power of Two (kekuatan dua orang) untuk Meningkatkan Hasil Belajar Bahasa Indonesia pada Siswa Kelas VII-B SMP Negeri 3 Tapung. PAJAR (Pendidikan dan Pengajaran) Program Studi Pendidikan Guru Sekolah Dasar FKIP Universitas Riau, 2 (6), 851-855.

Nurbaini. (2020). Penerapan Model Pembelajaran Kooperatif Tipe The Power Of Two untuk Meningkatkan Hasil Belajar IPS Siswa. Pendidikan dan Pengajaran, 4 (1), 278.

Nurbudiyani, Iin. (2013). Pelaksanaan Pengukuran Ranah Kognitif, Afektif, dan Psikomotor pada Mata Pelajaran IPS Kelas III SD Muhammadiyah Palangkaraya. Pedagogik Jurnal Pendidikan, 8 (2), 18.

Pratomo, R. H. S. (2017). Perbandingan Model Pembelajaran Kooperatif Tipe The Power Of Two Dengan Tipe Make A Match Dalam Pembelajaran Biologi (Studi Tentang Aktivitas, Respon, Dan Hasil Belajar Siswa). Jurnal Biotek, 5(1), 36-52.

Purwanto. (2010). Metodologi Penelitian Kuantitatif. Yogyakarta: Pustaka Pelajar.

Rosa, F. O. (2015). Analisis Kemampuan Siswa Kelas X pada Ranah Kognitif, Afektif dan Psikomotorik. Omega: Jurnal Fisika dan Pendidikan Fisika, 1(2), 24-28

Umar, Elmia. (2011). Peningkatan Hasil Belajar Siswa Sekolah Dasar melalui Belajar Kooperatif Tipe Jigsaw. Inovasi, 8 (3), 105.

Valia R, Sudiyanto, dan Ivada E. (2015). Model Pembelajaran Kooperatif Kombinasi Peer Tutoring dan Teams Games Tournament pada Pembelajaran Akuntansi. Jounal Tata Arta, 1 (3), 361-370.

Witarsa, Ramadhan, Galih Dani Septiyan Rahayu, Naning Sriningsih, Nurhayati, Sarce Tellusa, dan Purwati. (2017). Meningkatkan Kemampuan Aspek Psikomotorik Siswa Sekolah Dasar Melalui Hands on Activity di Kota Cimahi. Basicedu, 1 (1), 63. 